\title{
PENERAPAN AKAD MUDHOROBAH DALAM MENINGKATKAN PENDAPATAN KOPERASI KONSUMEN SYARIAH (KKS)
}

\author{
Oleh \\ Dewi Fitrotus Sa'diyah \\ Institut Agama Islam Pangeran Diponegoro Nganjuk
}

\begin{abstract}
In recent years the Islamic economy through Islamic banks has been in great demand by the public. Islamic economics is an alternative because in the process there is a balanced profit sharing principle, in this case no one party is harmed. The number of enthusiasts certainly has an impact on the establishment of Islamic financial institutions such as Syariah Consumer Cooperatives in various parts of the village. Moreover, its flexible nature is able to create its own market, namely rural communities or those in remote areas. In Islamic economics there is a mudharabah agreement that is a contract of business cooperation between two parties, where the first party (shahibul mal) provides capital while the other party is the manager. The money manager or in this case Barokah Tanjunganom KKS is doing his best to increase income.
\end{abstract}

Keywords: Mudharabah Agreement, Income Increase, Syariah Consumer Cooperative

\begin{abstract}
Abtsrak
Belakangan ini eknomi Islam melalui bank Syariah banyak diminati oleh masyarakat. Ekonomi syariah menjadi alternatif karena dalam prosesnya terdapat prinsip bagi hasil yang imbang, dalam hal ini tidak ada salah satu pihak yang dirugikan. Banyaknya peminat tentu berdampak pada pendirian lembaga keuangan syariah seperti Koperasi Konsumen Syariah di berbagai pelosok desa. Apalagi sifatnya yang fleksibel mampu menciptakan market tersendiri yaitu masyarakat pedesaan atau mereka yang berada di tempat terpencil sekalipun. Dalam ekonomi Islam terdapat Akad mudharabah yaitu akad kerjasama usaha antara dua pihak, dimana pihak pertama (shahibul mal) menyediakan modal sedangkan pihak lainnya sebagai pengelola.
\end{abstract}


Pengelola uang atau dalam hal ini KKS Barokah Tanjunganom berusaha semaksimal untuk meningkatkan pendapatan.

Kata Kunci: Akad Mudharabah, Peningkatan Pendapatan, Koperasi Konsumen Syariah

\section{Pendahuluan}

Perkembangan ekonomi Islam saat ini di Indonesia mengalami pertumbuhan yang signifikan. Berdasarkan data statistik perbankan syariah Bank Indonesia bulan September 2010, secara kuantitas, pencapaian perbankan syariah terus mengalami peningkatan dalam jumlah bank. Semenjak berdirinya Bank Muamalat Indonesia tahun 1992 sampai 2005 hanya ada tiga Bank Umum Syariah (BUS), 19 Unit Usaha Syariah (UUS), dan 92 Bank Pembiayaan Rakyat Syariah (BPRS) dengan total jumlah kantor baru mencapai 550 unit, dalam rentang lima tahun (2005- 2010), pertumbuhan perbankan syariah lebih dari dua kali lipat jumlah BUS saat ini telah mencapai 10 unit dengan 23 UUS dan jumlah BPRS telah mencapai 146 unit dan total jumlah kantor syariah sebanyak 1,640 unit $^{57}$. Secara geografis, sebaran jaringan kantor perbankan syariah juga telah menjangkau masyarakat di lebih dari 89 kabupaten/kota di 33 provinsi.

Keberhasilan Perbankan Syariah di Tanah air tidak bisa dilepas dari peran Lembaga Keuangan Mikro Syariah (LKMS). Kedudukan LKMS yang antara lain dipersentasikan oleh Bank Perkreditan Rakyat Syariah (BPRS), Baitul Maal Wat Tamwil (BMT) Koperasi Pesantren (KOPONTREN), Koperasi Konsumen Syariah (KKS) sangat vital menjangkau transakasi syariah di daerah yang tidak bisa dilayani oleh bank umum maupun bank yang membuka unit syariah.

KKS adalah koperasi yang beroperasi berdasarkan syariah atau prinsip agama Islam. Sesuai dengan prinsip Islam yang melarang sistem bunga atau riba yang memberatkan, maka KKS beroperasi

${ }^{57}$ Ali Rama, Ekonomi Syariah dan Outlook 201, 2010, http://ekonomiislami.wordpress.com(31 Desember 2017) 
berdasarkan kemitraan pada semua aktivitas bisnis atas dasar kesetaraan dan keadilan.

Kenyataan itu membuktikan bahwa sistem ekonomi syariah dapat diterima dan diterapkan dalam masyarakat Indonesia bahkan mempinyai nilai positif membangun masyarakat Indonesia dalam kegiatan ekonomi sekaligus membuktikan kebenaran hukum ekonomi syariah mempunyai nilai lebih dibandingkan dengan sitem ekonomi komunis maupun ekonomi kapitalis.

Indonesia yang masyarakatnya mayoritas bergama Islam adalah lahan subur untuk berkembangnya ekonomi syariah. Semakin tinggi kualitas kemampuan seseorang dan integritas diniyahnya akan semakin tertarik untuk menerapkan sistem ekonomi syariah dari pada yang lain. Hal ini disebabkan oleh panggilan hati nurani dan semangat jihad yanbg membakar keteguhan jiwanya memperjuangkan ajaran agama dalam segala unsur dunia.

Fenomena syariah mulai bermunculan di Indonesia, salah satunya adalah lembaga keuangan mikro swasta berprinsip syariah seperti Koperasi Konsumen Syariah (KKS) Barokah di Tanjunganom yang bergerak mengikuti peraturan Kementerian Koperasi. KKS Barokah Tanjunganom adalah salah satu wujud nilai syariah dalam bentuk lembaga keuangan mikro.

Salah satu lembaga keuangan syariah di Kecamatan Tanjunganom Nganjuk ini berperan aktif untuk membantu permodalan para usaha mikro dan kecil di Kecamatan tersebut. Koperasi ini mampu berkembang dengan memiliki jumlah nasabah sebesar 460 orang pada tahun 2015, kemudian tercatat April 2016 mengalami peningkatan sebesar 509 orang yang terus bertambah pada tahun 2017 menjadi 558 orang dengan terus berusaha memenuhi keinginan dan kebutuhan para mitra dengan berbagai programprogram yang menarik seperti si haji, si umroh dan lainnya. Koperasi Syariah Barokah Tanjunganom mengalami penurunan jumlah nasabah mudhorobah sebesar 250 orang pada tahun 2015, kemudian tercatat 
April 2016 mengalami penurunan sebesar 235 orang yang terus berkurang pada tahun 2017 menjadi 218 orang.58

\section{Medote Penelitian}

Metode yang digunakan dalam penelitian ini adalah pendekatan kualitatif. Pendekatan kualitatif tersebut yaitu "Suatu prosedur penelitian yang menggunakan data deskriptif berupa katakata tertulis atau lisan dari orang-orang atau perilaku yang dapat diamati". dalam penelitian ini peneliti menggunakan pendekatan diskriptif. Pada umumnya penelitian deskriptif tidak menggunakan hipotesis (non hipotesis) sehingga dalam penelitianya tidak perlu merumuskan hipotesis. Sedangkan jenis penelitian ini yang digunakan adalah studi kasus yaitu penelitian yang digunakan secara intensif, terinci dan mendalam terhadap suatu organisasi, lembaga atau gejalagejala tertentu.

Data yang digunakan dalam penelitian ini yaitu data yang diklasifikasikan maupun dianalisa untuk mempermudah dalam menghadapkan pada permasalahan ,memperolehnya bisa dari pimpinan, pegawai dan nasabah di Koperasi Koperasi Syariah Barokah Tanjunganom. Data-data tersebut diperoleh dari dua sumber, yaitu: (a) Data primer, kata-kata atau ucapan lisan dan perilaku manusia merupakan data utama atau data primer dalam suatu penelitian. Data primer diperoleh dari sumbernya secara langsung, diamati dan dicatat secara langsung, seperti wawancara, observasi, dan dokumentasi. Data primer adalah data yang bersumber dari informan yang mengetahui secara jelas dan rinci mengenai masalah yang sedang diteliti.59 Data primer dalam hal ini adalah dari Kepala Koperasi Koperasi Syariah Barokah Tanjunganom, Pegawai Koperasi Koperasi Syariah Barokah Tanjunganom, dan nasabah Koperasi Koperasi Syariah Barokah Tanjunganom.

58 Wawancara dengan Vebri Perwira R, Selaku Manager KKS Barokah Tanjunganom Nganjuk pada tanggal 13 Januari 2018.

${ }^{59}$ Sukidin,dkk, Managemen Penelitian . Surabaya .Insan Cendikia, 2002,13 . 
(b) Data sekunder, data sekunder dalam penelitian ini didapat dari pihak yang masih ada hubunganya dengan Koperasi Syariah Barokah Tanjunganom, akan tetapi tidak secara langsung mengetahui pengaruh penerapan akad mudhorobah terhadap pendapatan Koperasi Syariah Barokah Tanjunganom atau berhubungan langsung dengan Koperasi Syariah Barokah Tanjunganom ini didapat dari data yang sudah ada dan mempunyai hubungan masalah yang diteliti yaitu meliputi literature-literature yang ada.

Pengumpulan data dalam penelitian ini dilaksanakan dengan melakukan observasi secara langsung dengan menggunakan instrument pedoman wawancara, observasi secara langsung maka peneliti akan mendapatkan gambaran mengenai kondisi serta hal-hal apa saja yang terjadi selama kegiatan pelayanan berlangsung serta kondis nasabah saat pelayanan. Pedoman wawancara dapat dipergunakan untuk mendapat data yang lebih mendalam. Dan tes dapat dipergunakan untuk mendapatkan data kualitatif yang berupa deskripsi dari nasabah. Pada penelitian ini teknik pemeriksaan yang digunakan adalah derajat kepercayaan (credibility), yaitu untuk membuktikan kesesuaian antara hasil pengamatan dengan kenyataan lapangan.

\section{Hasil Dan Pembahasan}

\section{Penerapan Prinsip Mudhorobah di KKS Barokah}

Secara teknis, mudharabah adalah akad kerja sama usaha antra dua pihak, dimana pihak pertama (shahibul mal) menyediakan modal, sedangkan pihak lainnya menjadi pengelola. Karena sifatnya itulah mudharabah lebih praktis untuk dijalankan pada perbankan Islam dibandingkan dengan syirkah. Berikut ini adalah syarat Pembiayaan Mudharabah Koperasi Konsumen Syariah Barokah yaitu:

a. Menjadi anggota KKS Barokah dengan membuka rekening minimal Rp. 10.000,-,

b. Fotokopi Kartu Tanda Penduduk (KTP) suami \& istri,

c. Fotokopi Kartu Keluarga (KK),

d. Fotokopi surat nikah (dan atau surat cerai dan atau surat kematian), 
e. Surat Keterangan RT,

f. SIUP, TDP dan keterangan lain mengenai usaha,

g. NPWP (untuk pembiayaan di atas Rp 30 juta),

h. Rekening listrik, air, telepon,

i. Fotokopi jaminan dan surat/ keterangan pendukung,

j. Denah rumah, tempat usaha dan jaminan (jika jaminan berupa tanah),

k. Wawancara dan survey

Rukun Pembiayaan Mudharabah di Koperasi Konsumen Syariah Barokah antara lain: (a) dharib (pengelola usaha = nasabah/anggota). (b) Syarat: WNI, pemilik usaha, muslim atau non muslim (diutamakan muslim), (c) Shohibul maal (KKS), (d) Jumlah dana yang dimudharabah, (e) Akad (ijab qabul), Isi akad (ijab qabul) meliputi: Perjanjian antara KKS BAROKAH dengan mudharib, jumlah (nominal) dana, jangka waktu pembiayaan, nisbah bagi hasil, biaya - biaya, jaminan, tambahan tambahan (hal - hal di luar perkiraan atau tambahan - tambahan lain).

Mudharabah terbagi atas dua jenis, yakni yang bersifat tidak terbatas (muthlaqah, unrestricted) dan yang bersifat terbatas (muqayyadah, restricted). Jenis-jenis mudharabah dapat diuraikan sebagai berikut:

\section{a. Mudharabah Muthlaqah}

Pada jenis mudharabah yang ini pertama pemilik dana memberikan otoritas dan hak sepenuhnya kepada mudharib untuk menginvestasikan atau memutar uangnya.Mudharabah mutlaqah (investasi tidak terikat) yaitu pihak pengusaha diberi kuasa penuh. Untuk menjalankan proyek tanpa larangan atau gangguan apapun urusan yang berkaitan dengan proyek itu dan tidak terkait dengan waktu, tempat, jenis, perusahaan dan pelanggan.Investasi tidak terkait ini pada Bank Syari"eah diaplikasikan pada produk tabungan dan deposito. Dari penerapan mudharabah muthlaqah ini dikembangkan produk tabungan dan deposito, sehingga terdapat dua jenis produk penghimpunan dana, yaitu tabungan mudharabah dan deposito mudharabah. Adapun ketentuan umum dalam produk ini adalah sebagai berikut: 
1) Bank wajib memberitahukan kepada pemilik dana mengenai nisbah dan tata cara pemberitahuan keuntungan dan atau pembagian keuntungan secara resiko yang dapat ditimbulkan daripenyimpanan dana. Apabila telah tercapai kesepakatan, maka hal tersebut harus dicantumkan dalam akad.

2) Untuk tabungan mudharabah, bank dapat memberikan buku tabungan sebagai bukti penyimpanan, serta kartu ATM dan atau alat penarikan lainya kepada penabung. Untuk deposito mudharabah, bank wajib memberikan sertifikat atau tanda penyimpan (bilyet) deposito kepada deposan.

3) Tabungan mudharabah dapat diambil setiap saat oleh penabung sesuai dengan perjanjian yang disepakati, namun tidak diperkenakan mengalami saldo negatif.

4) Deposito mudharabah hanya dapat dicairkan sesuai dengan jangka waktu yang telah disepakati. Deposito yang diperpanjang, setelah jatuh tempo akan diperlakukan sama seperti deposito baru, tetapi bila pada akad sudah dicantumkan perpanjangan otomatis maka tidak perlu dibuat akad baru.

5) Ketentuan-ketentuan yang lain yang berkaitan dengan tabungan dan deposito tetap berlaku sepanjang tidak bertentangan dengan prinsip syarieeah.

\section{b. Mudharabah Muqayyadah}

Pada jenis mudharabah kedua ini, pemilik dana memberi batasan kepada mudharib. Di antara batasan itu, misalnya, adalah jenis investasi, tempat investasi, serta pihak-pihak yang diperbolehkan terlibat dalam investasi. Pada jenis ini shahibul maal dapat pula mensyaratkan kepada mudharib untuk tidak mencampurkan hartanya dengan dana al mudharabah. Adapun kerakteristik jenis simpanan ini adalah sebagai berikut:

1) Sebagai tanda bukti simpanan bank menerbitkan bukti simpanan khusus. Bank wajib memisahkan dana ini dari rekening lainya. Simpanan khusus dicatat pada pos tersendiri dalam rekening administratif.

2) Dana simpanan khusus harus disalurkan secara langsung kepada pihak yang diamanatkan oleh pemilik dana. 
3) Bank menerima komisi atas jasa mempertemukan kedua pihak. Sedangkan antara pemilik dana dan pelaksana usaha berlaku nisbah bagi hasil.

Ketentuan Pembiayaan Mudharabah Koperasi Konsumen Syariah Barokah yaitu (a) Pembiayaan mudharabah muqayyadah dengan jaminan; (b) Pada prinsipnya, dalam pembiayaan mudharabah tidak ada jaminan, namun agar mudharib tidak melakukan penyimpangan, Koperasi Konsumen Syariah Barokah meminta jaminan dari mudharib. Jaminan ini hanya dapat dicairkan apabila mudharib terbukti melakukan pelanggaran terhadap hal-hal yang telah disepakati bersama dalam akad; (c) Mudharib boleh melakukan berbagai macam usaha yang telah disepakati bersama dan sesuai syariah, Koperasi Konsumen Syariah Barokah tidak ikut serta dalam manajemen perusahaan atau proyek tetapi mempunyai hak untuk melakukan pembinaan dan pengawasan; (d) Koperasi Konsumen Syariah Barokah membiayai 100\% kebutuhan suatu proyek (usaha) bertindak sebagai pemilik dana (shahibul maal), sedangkan nasabah bertindak sebagai pengelola dana (mudharib), sejauh ini Koperasi Konsumen Syariah Barokah lebih banyak memberikan pembiayaan mudharabah untuk bentuk usaha yang tidak fluktuatif; (e) Jangka waktu usaha (maksimal 2 tahun), tata cara pengembalian dana (angsuran per minggu, per bulan, per triwulan) dan pembagian keuntungan (dengan revenue sharing sebesar nisbah yang disepakati) ditentukan berdasarkan kesepakatan Koperasi Konsumen Syariah Barokah dengan nasabah; (f) Koperasi Konsumen Syariah Barokah menanggung semua kerugian akibat dari mudharabah kecuali jika mudharib melakukan kesalahan yang disengaja, kelalaian (seperti pengelolaan yang kurang baik) atau menyalahi perjanjian; (g) Membuat laporan keuangan untuk pertanggung jawaban mudharib kepada Koperasi Konsumen Syariah Barokah.

\section{Penentuan Bagi Hasil Pembiayaan Mudharabah}

Penentuan bagi hasil pada pembiayaan mudharabah di Koperasi Konsumen Syariah Barokah menggunakan mekanisme revenue sharing. Revenue sharing yaitu pembagian bagi hasil diambil 
dari pendapatan yang diperoleh mudharib (pengelola dana) tanpa dikurangi biaya usaha. Besar nisbah (persentase) untuk Koperasi Konsumen Syariah Barokah dan mudharib ditentukan sesuai kesepakatan bersama. Jumlah nisbah yang diperoleh Koperasi Konsumen Syariah Barokah diusahakan tidak kurang dari tingkat margin per bulan yang telah ditentukan Koperasi Konsumen Syariah Barokah. Margin tidak selalu diberitahukan kepada mudharib.

Penentuan besar margin berdasarkan jumlah dari biaya dana (seperti untuk bagi hasil simpanan dan pengembalian pinjaman kepada pihak ketiga), biaya operasional (seperti untuk biaya perlengkapan kantor dan biaya gaji) dan keuntungan yang diambil Koperasi Konsumen Syariah Barokah. Misalnya:

1) Modal per bulan 1 milyar

2) Biaya dana per bulan Rp. 10.000.000,-

3) Biaya operasional per bulan Rp. 5.000.000,-

4) Keuntungan yang diinginkan per bulan $0,5 \%$

$(0,5 \%$ X 1 milyar $=$ Rp. $5 \cdot 000.000,-)$

Jadi, margin per bulannya adalah:

Biaya dana per bulan Rp. 10.000.000,-

Biaya operasional per bulan Rp. 5.000.000,-

Keuntungan yang diinginkan per bulan Rp. 5.000 .00

Margin per bulan $(\mathrm{Rp})$

Rp. 20.000.000, Margin per bulan (\%)

Rp. 20.000.000, $-\mathrm{X} 100 \%$ Rp.1.000.000.000,-

Contoh transaksi:

Koperasi Konsumen Syariah Barokah memberikan pembiayaan mudharabah kepada Tn. A dan Tn. B, sebesar:

1) Tn. A sebesar Rp. 10.000.000,-, pendapatan Rp. 2.000.000,-, nisbah bagi hasil untuk mudharib 85\% dari pendapatan (Rp. 
1.700.000,-), nisbah bagi hasil untuk Koperasi Konsumen Syariah Barokah 15\% (Rp. 300.000,-)

2) Tn. B sebesar Rp. 10.000.000,-, pendapatan Rp.1.000.000,-, nisbah bagi hasil untuk mudharib $70 \%$ dari pendapatan (Rp .700.000,-), nisbah bagi hasil untuk Koperasi Konsumen Syariah Barokah 30\% (Rp. 300.000,-)

Besar nisbah yang diambil antara pembiayaan yang diberikan kepada Tn. A dan Tn. B berbeda karena untuk menghindari kerugian bagi KKS, sehingga nisbah yang diterima Koperasi Konsumen Syariah Barokah tidak lebih kecil dari margin yang ditentukan Koperasi Konsumen Syariah Barokah yaitu sebesar Rp.200.000,--

KKS selalu melihat positif, dalam arti orang berusaha pasti mencari untung. Kalaupun rugi itu semata-mata karena Allah menentukan lain. Oleh karena itu apabila mengalami kerugian maka ditanggung oleh Koperasi Konsumen Syariah Barokah kecuali segala macam kerugian yang diakibatkan karena kelalaian/ kecerobohan atau penyelewengan pengelola usaha, ditanggung sendiri oleh mudharib.

\section{Alur Penyelenggaraan Pembiayaan Mudharabah}

Alur penyelenggaraan pembiayaan mudharabah dimulai dari nasabah mendaftar melalui marketing officer atau datang sendiri ke kantor Koperasi Konsumen Syariah Barokah menemui consumer service untuk mengajukan pembiayaan, memenuhi persyaratan lengkap serta deskripsi bentuk usaha jelas, setelah itu semua data dimasukkan di buku register permohonan, kemudian koordinator marketing melakukan survey dan analisis, kemudian mengadakan rapat komite (marketing officer, consumer service, koordinator marketing, kepala kantor) dan pengurus (untuk nominal tertentu), dari rapat tersebut untuk memutuskan pembiayaan yang diajukan diterima atau ditolak, jika pembiayaan ditolak maka dibuatkan surat penolakan atau menghubungi nasabah via telepon, jika pembiayaan diterima segera dijadwalkan untuk realisasi, pelaksanaan akad (ijab, qabul), kemudian realisasi pembiayaan. Realisasi pembiayaan diawali dengan 
pemberian modal kepada mudharib kemudian pelaksanaan usaha oleh mudharib dan pembagian nisbah sesuai kesepakatan.

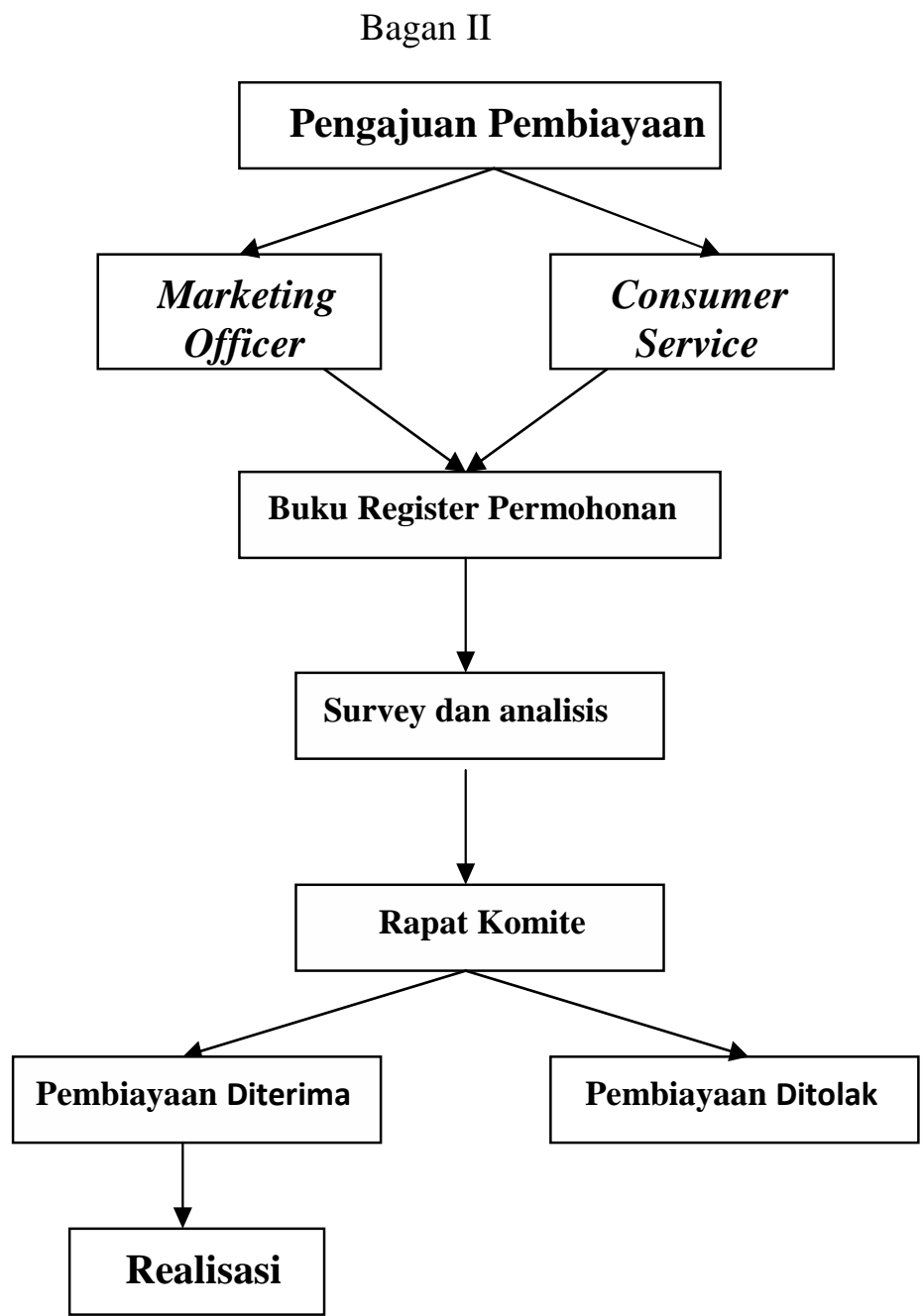

Gambar 2.2

Alur Mudharabah Koperasi Konsumen Syariah Barokah 


\section{Kendala dan Penyelesaian dalam Pelaksanaan Akad Mudhorobah}

Meski secara hukum Koperasi Syariah sudah lengkap, namun pada prakteknya masih terdapat kendala sehingga Koperasi Syariah tidak bisa berjalan maksimal sebagaimana tujuan awal. Ada beberapa faktor yang menjadi kendala yaitu Petama, keraguan masyarakat tentang prinsip Koperasi Syariah Maraknya perkembangan dan pertumbuhan bank syari'ah dipandang sinis oleh beberapa kalangan, bahkan kalangan umat Islam sendiri. Sinisme terhadap perbankan Islam tersebut dapat dilihat dari kepercayaan masyarakat Islam terhadap Bank Syari'ah sangat rendah. Bahkan beberapa ilmuwan muslim ada yang mengecam perbankan syari'ah, mereka berpendapat bahwa bank-bank Islam dalam menyelenggarakan transaksitransaksinya justru bertentangan dengan konsepnya. Dengan kata lain, bertentangan dengan semangat syari'ah. Dipertanyakan apakah penyelenggaraan kegiatan-kegiatan usaha-usaha bank-bank Islam tersebut, yang notabene bermaksud untuk menghindarkan pemungutan bunga dan bermaksud agar risiko dipikul bersama, apakah memang telah diselenggarakan sesuai dengan tujuan tersebut ataukah dalam pelaksanaannya ternyata hanya penggantian istilah belaka.

Masyarakat di kecamatan Tanjunganom sebagian masih ragu dengan prinsip-prinsip koperasi syariah dan konsistensi bisnis syariah karena sekarang banyak bermunjulan koperasi ataupun bank yang memakai label syariah, bagi masyarakat yang belum paham dengan prinsip-prinsip syariah masih berpikir ulang untuk melakukan investasi maupun mengambil bagian dari produk-produk yang ditawarkan oleh KKS Barokah karena sudah terbiasa menjadi anggota koperasi konvensional, Oleh karena itu KKS Barokah harus memperkenalkan produk-produk yang dimiliki agar masyarakat mengetahui produk syariah KKS Barokah dan memberi informasi bahwa produk tersebut sesuai dengan syariat islam.

Faktor kedua yaitu sumber daya manusia. Salah satu permasalahan perbankan syariah adalah terbatasnya SDM yang berkualitas, untuk membangun perbankan syariah yang professional, baik dan benar. Masih banyak SDM koperasi syariah yang belum 
memiliki pengetahuan dan pengalaman yang baik dalam menjalankan operasional koperasi syariah. Tak jarang ditemui SDM koperasi syariah yang kurang bisa memberikan penjelasan yang benar dan akurat. Sehingga menimbulkan keraguan bagi calon nasabah untuk menggunakan produk dan layanan koperasi syariah. Bahkan penjelasan yang sembarangan memunculkan anggapan keliru tentang koperasi syariah, sehingga akan memengaruhi pencitraan bank syariah.

Banyak faktor yang bisa membuat kualitas SDM bank syariah meningkat. Yaitu, bisa dilakukan dengan memberikan training hard skill tentang product knowledge secara berkesinambungan. Dan secara periodik melakukan pembahasan atas permasalahan yang muncul di lapangan, dan memberikan pembekalan keterampilan soft skill kepada mereka.

Kurang tersedianya SDM syariah sekarang ini, memang telah menjadi polemik yang tengah dihadapi lembaga keuangan syariah. Tidak hanya sekedar persoalan kualitas saja, melainkan secara kuantitas, juga menjadi sebuah persoalan yang perlu dibenahi. Sebab, disaat meningkatnya industri perbankan syariah, malah SDMnya merosot. Akibatnya bisnis ini menjadi timpang. Faktor SDM yang kurang yaitu kompetensi, laporannya harus jelas dan rinci walaupun tidak seperti akutansi, maka solusinya yaitu memberi buku kas debet kredit keluar masuk uang.

Sistem bagi hasil pada KKS Barokah Tanjunganom cenderung lebih tinggi mudhorobah dari pada murabahah maka dari itu kebanyakan calon nasabah lebih memilih murabahah. Beberapa bentuk skema bagi hasil mudhorobah, yaitu: 1) Profit-Sharing, sebagai dasar perhitungannya adalah profit yang diperoleh dari usaha yang dibiayai dengan kredit/pembiayaan. Profit merupakan selisih antara penjualan/pendapatan usaha dan biaya-biaya usaha, baik berupa harga pokok penjualan/biaya produksi, biaya penjualan dan biaya umum dan administrasi. Penggunaan istilah profit-sharing dalam hal ini juga merujuk pula pada istilah profit-and-loss sharing, mengingat besaran profit yang bisa bertanda positif (untung) atau negatif (rugi). 2. Gross Profit Sharing, dasar perhitungannya adalah gross 
profit (laba kotor), yakni penjualan/pendapatan usaha dikurang dengan harga pokok penjualan/biaya produksi. Dengan skema ini, pihak-pihak yang berkontrak tidak menghadapi kepastian di sisi biaya penjualan dan biaya umum dan administrasi. 3. Revenue-Sharing, dasar perhitungannya adalah penjualan/pendapatan usaha. Dalam hal ini pemilik dana hanya menghadapi kepastian atas tinggi rendahnya penjualan/pendapatan usaha dan tidak menghadapi ketidakpastian atas biaya-biaya usaha (harga pokok penjualan/biaya produksi, biaya penjualan dan biaya umum dan administrasi).

Alasannya beberapa pemilik dana (shahibul maal) menolak menggunakan skema bagi hasil antara lain disebabkan anggapan bahwa skema bagi hasil itu tidak efisien, sedangkan dari pihak pelaksana usaha (mudharib) disebabkan skema bagi hasil dinilai tidak incentive compatible. Penerapan skema bagi hasil tersebut diasosiasikan dengan tingginya biaya monitoring dan verifikasi, karena dengan skema bagi hasil standar (yang tidak didesain sedemikian rupa untuk mencapai optimalisasi pihak-pihak yang berkontrak) memang permasalahan moral hazard yang ditimbulkan besar dan sebagai implikasinya biaya monitoring dan verifikasi juga besar. Oleh karena itu, perlu di desain skema bagi hasil yang optimal, yang secara efisien dapat mendorong mudharib untuk menggunakan dananya dengan cara-cara dan upaya terbaik serta. Beberapa permasalahan yang dihadapi dalam penerapan skema bagi hasil, antara lain berupa tingginya biaya monitoring dan verifikasi untuk mengatasi permasalahan principal-agent berupa moral hazard. Di samping itu terdapat pula permasalahan adverse selection. Biaya monitoring dan verifikasi pada skema bagi hasil diperkirakan lebih besar daripada skema bunga. Monitoring dan verifikasi atas besarnya profit sangat menentukan besarnya pendapatan bagi hasil sehingga tentunya perlu dilakukan lebih intensif.

Solusinya dengan memberi wawasan bahwa mudhorobah lebih leluasa dalam mengelola dana karena pokok pembiayaan akan dikebalikan saat jatuh tempo, dengan hal tersebut para calon nasabah akan mengerti dan bisa berfikir ulang untuk memilih mudhorobah dari pada murobahah. 
Jenis usaha yang dapat dimudhorobahkan tidak banyak, yaitu jenis usaha yang bisa diaplikasikan dalam bentuk mudhorobah seperti usaha rumah makan, counter, serta usaha lain yang sudah pasti memiliki penghasilan tetap serta yang memiliki laporan keluar masuknya pendapatan serta usaha yang dimilki jelas dan tidak bertentangan dengan syariat agama. Sedangkan usaha yang tidak bisa dimudhorobahkan usaha yang tidak sesuai dengan syariat islam seperti usaha jualan minuman keras,jualan daging babi karna semua itu melanggar syariat islam.

Secara teknis, mudharabah adalah akad kerja sama usaha antra dua pihak,dimana pihak pertama (shahibul mal) menyediakan modal, sedangkan pihak lainnya menjadi pengelola. Karena sifatnya itulah mudharabah lebih praktis untuk dijalankan pada perbankan Islam dibandingkan dengan syirkah. Sesungguhnya, mudharabah sendiri dibagi menjadi dua, yaitu Mudharabah muthlaqah dan mudharabah muqayyadah. Mudharabah mutlaqah adalah jenis mudharabah yang cakupannya sangat luas dan tidak dibatasi oleh spesifikasi jenis usaha, waktu dan daerah bisnis. Sedangkan mudharabah muqayyadah adalah mudharabah yang diikat oleh waktu, jenis usaha ataupun tempat usaha. Maka dari itu calon penerima modal harus bisa menjelaskan tentang usahanya secara terperinci sehingga pemilik modal (KKS) akan bisa menerapkan dengan akad mudhorobah. Solusinya pihak KKS meminta deskripsi penjelasan usaha yang akan dilakukan dengan hal itu bisa dimengerti apakah usaha tersebut layak dalam sudut pandang islam untuk di biayaai agar bisa diatur menjadi pola mudhorobah.

\section{Penerapan Akad Mudhorobah Terhadap Pendapatan Koperasi KKS Barokah}

Secara teknis, mudharabah adalah akad kerja sama usaha antra dua pihak,dimana pihak pertama (shahibul mal) menyediakan modal, sedangkan pihak lainnya menjadi pengelola. Karena sifatnya itulah mudharabah lebih praktis untuk dijalankan pada perbankan Islam dibandingkan dengan syirkah. Sesungguhnya, mudharabah sendiri 
dibagi menjadi dua, yaitu Mudharabah muthlaqah dan mudharabah muqayyadah

Menurut para ahli Ekonomi Islam pada saat ini produk murabahah sudah mendominasi portofolio perbankan syariah, baik yang berbentuk Bank Umum, Bank Perkreditan Rakyat Syariah (BPRS) bahkan sampai pada tingkat Baitul Mal wat Tamwil (BMT), Lembaga Koperasi Syariah(LKS). Mengapa bank lebih memilih murabahah? Karena di dalam Fiqh tidak pernah mengatur portofolio produk sebuah lembaga keuangan syariah seperti bank, Tidak ada istilah proporsi halal atau haram dalam pengaturan portofolio produk atau jasa perbankan syariah. Oleh karena itu, adalah sah dan boleh saja bila sebuah bank syariah lebih mengutamakan menjual produk pembiayaan murabahah atau mudhorobah itu. Dalam bahasa lain, hal ini lebih bersifat kebijakan bisnis sebuah lembaga keuangan syariah, dan tergantung tentunya kepada kepentingan apa yang ada dibalik kebijakan itu.

Kemudian menurut para ahli Ekonomi Islam produk Murabahah selain sudah mendominasi portofolio perbankan syariah, produk Murabahah ternyata lebih menarik di banding dengan produk Mudharabah dan Musyarakah. Mengapa? Karena ada beberapa alasan yang pertama adalah bahwa produk Murabahah mudah diekivalenkan dengan pola perbankan konvensional. Konsekuensinya, produk ini mudah dipahami oleh bank dan masyarakat sekaligus. Oleh karena itu pula, produk ini mudah disosialisasikan. Kedua karena bentuknya yang mudah dipahami, maka juga mudah dilakukan perhitungan, sehingga produk murabahah relatif mudah dijual, dan sekaligus mengandung resiko kecil di mata bank.Oleh sebab itu, wajar bila perbankan syariah lebih menyukai dan membesarkan portofolio dalam bentuk produk murabaha tersebut.

Tetapi sesungguhnya produk mudharabah dan musyarakah tidak kalah penting juga dari produk Murabahah, sebab kedua produk tersebut merupakan dua produk perbankan syariah yang berpotensi sangat besar dalam menciptakan keseimbangan sektor moneter dan syariah serta pendapatan suatu perusahaan atau lembaga keuangan. Mengapa demikian? Karena kedua produk ini betul-betul melibatkan 
dua pihak yang sedang bergerak mengelola sektor usaha yang tidak usah diragukan memberikan nilai tambah pada gerakan ekonomi secara langsung. Tetapi mengapa bank jarang untuk memilih atau menggunakan produk Mudharabah dan Musyarakah? Karena Dalam kondisi riel di Indonesia, kendati mudharabah diakui mencapai ratarata $14,33 \%$ dari total pembiayaan yang dilakukan perbankan syariah, maka harus dipahami bahwa mudharabah yang dilakukan menempuh prosedur yang sangat dapat diperdebatkan.

Misalnya saja, bahwa hampir tidak ada pembiayaan mudharabah yang tidak melibatkan kontribusi modal pihak mudharib (penyedia jasa). Ini jelas tidak sesuai dengan aturan dasar mudharabah itu sendiri, karena bahwa dalam perjanjian mudharabah maka modal finansial sesungguhnya menjadi tanggung jawab pemilik modal atau shohibul maal. Sebaliknya, mudharib memang hanya cukup bertanggungjawab pada sisi ketrampilan dan operasional saja. Selain daripada itu produk Mudharabah banyak sekali resiko yang di keluarkan di bandingkan dengan produk Murabahah seperti yang telah di jelaskan sebelumnya. Resiko yang di timbulkan dari produk Mudharabah antara lain yaitu:

Pertama, mudah mengalami atau rentan terhadap penyimpangan, karena sering kali pihak mudharib tidak melengkapi diri dengan akuntanbilitas yang memadai dengan laporan keuangan yang auditable. Persoalan ini memang tidak mudah diatasi, karena berkaitan dengan buruknya budaya akuntansi di banyak perusahaan di negeri ini.

Kedua, di sisi lain, mudharabah menuntut prasyarat kejujuran dan keterbukaan, apalagi dalam konteks mudharabah ada sebuah pengertian bahwa pihak shohibul maal seakan-akan tidak mempunyai hak intervensi sedikitpun dalam proyek bisnis yang sedang dijalankan oleh pihak mudharib.

Ketiga, akibat dari dua kondisi di atas, seringkali pihak bank mematok nisbah bagi hasil yang barangkali relatif cukup besar bagi bank, dan sebaliknya lebih kecil bagi nasabah. Manakala nisbah bagi hasil tersebut diekivalenkan dengan tingkat bunga bank, akan terasa 
bahwa porsi yang harus dibayarkan pihak nasabah menjadi lebih mahal dibandingkan dengan bunga bank konvensional.

Jadi itulah perbandingan antara Mudharabah, Murabahah dan Musyarakah menurut para ahli Ekonomi Islam yang mana pada saat ini Produk Murabahah lebih banyak di gunakan dalam perbankan di bandingkan dengan Produk Mudharabah dan Musyarakah karena di mata bank produk Murabahah lebih memiliki resiko yang sagat kecil di bandingkan dengan Mudharabah. Tetapi apabila bank tidak dapat menggunakan produk Murabahah lagi para ahli Ekonomi Islam memberi solusi untuk lebih baik menggunakan produk Musyarakah di banding dengan Mudharabah, karena produk Musyarakah jauh lebih adil ketentuannya seperti yang telah di amati daripada Mudharabah.

Sedangkan Hasil penelitian mengenai penerapan akad mudhorobah terhadap pendapatan Koperasi KKS Barokah Tanjunganom, bahwa keuntungan yang diperoleh lebih besar pola pembiayaan mudhorobah dari pada pola murobahah karena presentase bagi hasilnya lebih besar, sedangkan pola murobahah presentase bagi hasilnya lebih kecil. Sehingga pada KKS Barokah Tanjunganom pendapatan terbesar dan yang lebih menguntungkan adalah pola pembiayaan akad mudhorobah.

\section{Kesimpulan}

Berdasarkan penelitian dapat disimpulkan bahwa produk simpanan KKS Barokah Tanjunganom menggunakan prinsip mudhorobah mutlaqoh, sedangkan produk pembiayaan menggunakan prinsip mudhorobah mukoyat. Faktor yang menjadi kendala dalam pelaksanaan akad mudhorobah yaitu a) Keraguan Masyarakat tentang Prinsip Koperasi Syariah, solusinya dengan memperkenalkan dan memberi informasi tentang produk syariah kepada calon nasabah bahwa produk tersebut sesuai dengan syariat islam. b) Faktor Sumber Daya Manusia yang kurang berkualitas, solusinya yaitu memberi buku kas debet kredit keluar masuk uang. c) Sistem bagi hasil yang terlalu tinggi, solusinya memberi wawasan bahwa mudhorobah lebih leluasa dalam mengelola dana karena pokok pembiayaan akan dikebalikan saat jatuh tempo. d) Jenis usaha yang dapat dimudhorobahkan 
terbatas, solusinya Solusinya pihak KKS meminta deskripsi penjelasan usaha yang akan dilakukan dengan hal itu bisa dimengerti apakah usaha tersebut layak dalam sudut pandang islam untuk di biayaai agar bisa diatur menjadi pola mudhorobah. d) Penerapan Akad Mudhorobah terhadap Pendapatan Koperasi KKS Barokah Tanjunganom bahwa keuntungan yang diperoleh lebih besar pola pembiayaan mudhorobah dari pada pola murobahah karena presentase bagi hasilnya lebih besar, sedangkan pola murobahah presentase bagi hasilnya lebih kecil.

\section{Daftar Pustaka}

Abu Abdullah Muhammad, Ensiklopedia Hadits Sunan Ibnu Majah, Jakarta: Almahira, 2013, h. 407

Ali Rama, "Ekonomi Syariah dan Outlook 2011", artikel diakses pada 31

Andri Soemitra, Bank \& Lembaga Keuangan Syariah, Cet. I (Jakarta: Kencana Prenada Media Group,2009),h.53

Andri Soemitra, Bank \& Lembaga Keuangan Syariah, Cet.I (Jakarta: Kencana Prenada Media Group,2009), h.29.

Anita, Mega. Utami. Pengaruh Pembiayaan Mudharabah Terhadap Pendapatan Bmt Bina Umat Sejahtera Pondok Gede.Skripsi. UIN Syarifn Hidayatullah. 2011

Anonim. 2008. Peraturan Bank Indonesia Nomor: 10/16/PBI/2008

Tentang Pelaksanaan Prinsip Syariah dalam Kegiatan Penghimpunan Dana dan Penyaluran Dana serta

Pelayanan Jasa Bank Syariah. http://www.bi.go.id.pdf/. 29 juni 2009.

Antonio, Syafi'iMuhammad. 2001. Bank Syariah dari Teori ke Praktik. Jakarta: Gema Insani Press.

Arikunto, Suharsimi. 2006. Prosedur Penelitian Suatu Pendekatan Praktik. Edisi Revisi VI. Jakarta: PT Rineka Cipta.Budisantoso, Totok dan Sigit Triandaru. 2006. Bank dan Lembaga keuangan lain. Edisi 2. Jakarta: Salemba Empat. 
Desember

http://ekonomiislami.wordpress.com/2010/12/31/ekonomisyariah-dan-outlook-2011

Hamidi , M. Lutfi. Jejak-Jejak Ekonomi Syariah. Senayan Abadi Publishing, Jakarta. 2003. h.79.

Heri Sudarsono, Bank Dan Lembaga Keuangan Syari'ah, (Yogyakarta : Ekonisia 2004), hlm. 60.

http://contohskripsi-makalah.blogspot.com/2012/08/keabsahan-datainstruman-penelitian.html (diakses tanggal 23 April 2018, pukul 18.04 WIB).

http://mirsadakbar.blogspot.co.id/2013/09/antara-tabungan-wadiahdan-tabungan.html pada 27-11-2017 jam 14.07 WIB

J.Supranto, Statistik: Teori dan Aplikasi, Jilid II, Ed.4 (Jakarta: Erlangga, 2001), h. 201.

Kasmir. Bank dan Lembaga Keungan Lainnya Edisi Keenam. Jakarta: PT. Raja Grafindo Persada. 2015.1-2.

KKS. Sejarah berdirinya kks barokah. Barokah Publishing. Nganjuk. 1998),h 1.

M. Lutfi Hamidi, Jejak-jejak Ekonomi Syariah(Jakarta: Senayan Abadi Publishing, 2003), h.79

Muhammad, Manajemen Bank Syari'ah, (Yogyakarta: UPP AMP YKPN) hal. 104

Nawawi, Ismail. Ekonomi Kelembagaan Syariah. Surabaya: Putra Media Nusantara. . 2009.108.

Nurul Huda, Ekonomi Mikro Islam (Jakarta: Prenada Nedia Group, 2009), h. 21

Putri, Alfiani Gistyaning. Metode Pengumpulan Data (Online), 2016, https://fitwiethayalisyi.wordpress.com (11 Januari 2018)

Rama, Ali. 2011. Ekonomi Syariah dan Outlook 2011. artikel diakses pada $31 \quad$ Desember $2017 \quad$ dari http://ekonomiislami.wordpress.com /2010/12/31/ekonomisyariah-dan-outlook-2011

Sakti, Ali. 2005. TOT Perbankan Syariah (Fakultas Ekonomi UNS dan BankIndonesia). Surakarta: tidak dipublikasikan. 
Soim dkk, Pedoman Penyusunan Skripsi. Nganjuk: Lembaga Penerbitan IAI Pangeran Diponegoro Nganjuk, 2014, 21.

Sugiono, Meteode Penelitian Kuantitatif, Kualitatif dan $R \& D$, Bandung: ALFABETA, 2013, 326.

Suharsini Arikunto. Prosedur Penelitian Suatu Pendekatan Praktik. Rineka Cipta. Jakarta. 2013, 275

Sukidin,dkk, Managemen Penelitian . Surabaya .Insan Cendikia, 2002,13.

Sunaryo, Hukum Lembaga Pembiayaan, Cet.II ( Jakarta: Sinar Grafika, 2009)

Sutan Remy Sjahdeini, Perbankan Syariah, Jakarta: Kencana, 2014.

Totok Budi Santoso dan Sigit Triandaru, Prinsip Operasional Koperasi Konsumen Syariah, ( 2006: 153).

Veithzal Rivai, dkk, Bank and Finansial Institution Management(Jakarta: PT. Raja Grafindo Persada, 2007).

Wiroso, Penghimpunan Dana Dan Distribusi Hasil Usaha Bank Syari'ah, Jakarta: PT Grasindo 2005 